боті дерматовенерологічної служби. Украӥнський журнал дерматології, венерологї̈, косметологіï. 2013. № 3. С. 10-15.

13. Степаненко В.І., Короленко В.В., Богомолець О.В. Сучасні організаційні підходи до контролю за захворюваністю на меланому: світовий та український досвід. Український журнал дерматології, венерологіï, косметологіï. 2013. № 4. С. 20-24.

14. Щорічна доповідь про стан здоров'я населення, санітарноепідемічну ситуацію та результати діяльності системи охорони здоров'я України. 2017 рік / Укр. ін-т стратег. дослідж. МОЗ України ; редкол.: П. С. Мельник [та ін.]. - Київ : Медінформ, 2018. - 458 с.

DOI https://doi.org/10.30525/978-9934-588-81-5-2.51

\title{
CALCULATION AND HYGIENIC ESTIMATION OF POTENTIAL POLLUTION OF WATER SUPPLY SOURCES BY BICYCLOPYRONE
}

\author{
Korshun M. M. \\ Doctor of Medical Science, \\ Professor at the Hygiene and Ecology Department № 3 \\ Bogomolets National Medical University \\ Martiianova Y. V. \\ Assistant at the Hygiene and Ecology Department № 3 \\ Bogomolets National Medical University \\ Ghorbachevskyi R. V. \\ Candidate of Medical Science, \\ Associate Professor at the Hygiene and Ecology Department № 3 \\ Bogomolets National Medical University \\ Kyiv, Ukraine
}

In order to prevent significant loss of raw agricultural materials and food products due to weed, fungal diseases and various pests, civilization continues to use large amounts of chemical plant protection products (CPPP). Pesticides, and in particular herbicides, on one hand provide a higher crop yield though on the other hand, residual accumulation builds up throughout the crops. Therefore, despite the benefits of a high crop yield being able to ensure that there is enough food provided for the population, CPPP can have a negative impact on human health.

The negative impact that can be seen through the use of CPPP on crops can be detrimental to a population's health, as there are several acute and 
chronic diseases that can have long-term consequences on the consumer; including carcinogenesis and reproductive dysfunction. It is also possible that the toxicity of said CPPPs can also migrate to our water supplies, so toxicological and hygienic assessments of new pesticides is crucial in ensuring that both the centralized and decentralized water supplies are not contaminated.

The aim of our study is to forecast and assess the potential contamination of both surface and groundwater sources due to the use of the herbicide bicyclopyrone, based on data accumulated from its physicochemical attributes.

The stability of bicyclopyrone has been studied in different types of soils: loam, sandy-clay loam, clay loam, silty loam, silty clay loam, silty clay, loamy sand $[1$, p. 48,50$]$. The half-life periods $\left(\mathrm{DT}_{50}\right)$ of the substance fluctuated in a wide range depending on soil and climatic conditions: in laboratory experiments - 19.8-434 days, in field experiments 1.7-36 days [2, p. 29]. According to «Hygienic classification of pesticides and agrochemicals» State Standards 8.8.1.002-98 [3, p. 249-266] according to stability in soil in laboratory conditions bicyclopyrone can be appertain to both to moderately stable (III class), and to highly stable (I class) pesticides; in fields - both to unstable (IV class) and to stable (II class) pesticides. According to the international classification IUPAC, bicyclopyrone is also classified from unstable (III class) to highly stable (I class) in the laboratory and moderately stable (II class) in the field.

Method of M.M. Melnikov [4, p. 72-74] was used to assess the potential risk of bicyclopyrone on terrestrial biocenosis and calculated its ecotoxicological hazard (ecotox) taking into account the maximum rate of consumption $(0.15 \mathrm{~kg} / \mathrm{ha})$. The ecotox ranged from $7.28 \times 10^{-6}$ to $1.54 \times 10^{-4}$; was lower than ecotox sim-triazines herbicides [5, p. 67], and comparable to the ecotox of modern imidazolinones [6, p. 375], oxazole [7, p. 63] and sulfonylureas $[8$, p. 60] herbicides.

Evaluating the mobility of bicyclopyrone in the soil by sorption, in terms of organic carbon $\left(\mathrm{K}_{\mathrm{oc}} 6-500 \mathrm{ml} / \mathrm{g},[2, \mathrm{p} .30]\right)$, it was found that in the vast majority of tested soils the substance can be classified as class I (very mobile), while in some soils - even up to IV class (little mobile) according to the international classification SSLRC (Soil Survey and Land Research Center) [9, p. 18].

The danger of bicyclopyrone migration into water sources was assessed by leaching potential index GUS and index LEACH, which we calculated based on $\mathrm{DT}_{50}, \mathrm{~K}_{\mathrm{oc}}$ and solubility in water [1, p. 26; 2, p. 29-30], according to the formulas given in $[10$, p. 339-357; 11, p. 69-78]. The ability to remove bicyclopyrone from the soil to groundwater according to GUS $(0.3-8.5)$ is estimated from very low (V class) to very high (I class). The 
risk of potential contamination of groundwater and river water according to the LEACH index (404.6-714000) is considered to be high (I class).

To predict groundwater pollution by bicyclopyrone, the calculation of integrated vectors of hazard according to $\mathrm{R}$ was performed according to the method by S.G. Sergeev et al. [12, p. 76-79.]. The method involves an integrated assessment of 3 criteria: migration capacity - GUS, toxicity and cumulative - zone of biological effect $\left(Z_{\text {boil.ef.; }}\right.$; calculated based on the average lethal dose $\mathrm{LD}_{50} 5000 \mathrm{mg} / \mathrm{kg}$ and the verge of chronic effect $\mathrm{Lim}_{\mathrm{ch}} 0.28-0.35$ $\mathrm{mg} / \mathrm{kg}\left[2\right.$, p. 7.]) and stability in water - half-life $\tau_{50}[2$, p. 29]. Depending on soil and climatic conditions, the level of risk of bicyclopyrone groundwater pollution varies from high to very high ( $\mathrm{R}$ from 115.7 to 173.2 ).

To predict the risk of bicyclopyrone to human life and health, integral groundwater contamination hazard index (IGCHI) was determined based on LEACH, $\tau_{50}$ in water and the meaning of the acceptable daily intake for humans (ADI) according to [13]. It has been established that this herbicide is potentially extremely dangerous (class $1 \mathrm{~A}$ ) for the health of the population if it reaches groundwater and surface water sources.

To first get a combined risk estimation of the destructive effects on the human body by bicyclopyrone, when it reaches water, it was necessary to calculate the SCI-GROW (Screening Concentration In Ground Water) using the computer program from EPA official Website [15]. The calculation was performed taking into account the maximum rate of consumption $(0.15 \mathrm{~kg} / \mathrm{ha}), \mathrm{K}_{\mathrm{oc}}$ and $\mathrm{DT}_{50}$ in soil. SCI-GROW ranges from $6.41 \times 10^{-4}-2.52$ $\mu \mathrm{g} / \mathrm{l}$. It has been established that the risk of destructive effects of (R) bicyclopyrone when it reaches water ranges from $8.3 \times 10^{-5}$ to $3.2 \times 10^{-1}$, which is less than 1, ie the risk of destructive effects on human health is acceptable.

In conclusion, after examination the herbicide bicyclopyrone due to low sorption capacity, high solubility and stability in water and soil under certain soil and climatic conditions is characterized by a high probability of contamination of surface and groundwater, which threatens to adversely affect the human body in case of pollution of water sources. The final assessment of the risk to human health due to the use of bicyclopyrone in agriculture will be conducted after studies of its behavior in the system «soil - adjacent environments» have occurred, under the soil and climatic conditions of Ukraine.

\section{References:}

1. Malhat F. M. BICYCLOPYRONE(295). Central Agricultural pesticides Laboratory. Giza, Egypt. 2017. P. 26-50. URL: http://www.fao.org/ fileadmin/templates/agphome/documents/Pests_Pesticides/JMPR/ Evaluation2017/BICYCLOPYRONE__295_.pdf (Last accessed: 15.09.2020) 
2. Public release summary on the evaluation of the new active bicyclopyrone in the product Talinor Herbicide. Product Number [P82256]. Australian Pesticides and Veterinary Medicines Authority. 2017. P. 2-30. URL: https://apvma.gov.au/ sites/default/files/publication/26736-prsbicyclopyrone-talinor-herbicide.pdf (Last accessed: 15.09.2020)

3. Pestytsydy. Klasyfikatsiia za stupenem nebezpechnosti: DSanPiN 8.8.1.002-98 (Est. 28.08.98) / Zb. Vazhlyvykh ofitsiinykh materialiv z sanitarnykh i protyepidemichnykh pytan // Kyiv, 2000. Vol. 9, Ch. 1. P. 249-266 [in Ukrainian].

4. Melnikov N.N. K voprosu o zagryaznenii pochvy khlororganicheskimi soedineniiami. Agrokhimiia. 1996. № 10. S. 72-74.

5. Melnikov N.N. Sravnitelnaia opasnost zahrazneniia pochvy gherbitsydamy - proizvodnymi simm-triazinov i nekotorykh druhikh shestichlennykh gheterotsiklicheskikh soedinenii / N.N. Melnikov, S.R. Belan // Agrokhimiia. 1997. № 2. S. 67.

6. Ghihiienichna otsinka ekotoksykolohichnykh ryzykiv zastosuvannia imidazolinovykh gherbitsydiv / R.V. Ghorbachevskyi, M.M. Korshun // Zbirnyk naykovykh prats spivrobitnykiv NMAPO imeni P.L. Shupyka. Vypusk 21. Knyha 3. Kyiv, 2012. S. 373-377.

7. Ekoloho-hihiienichna otsinka zastosuvannia herbitsydiv - inhibitoriv atsetolaktatsyntetazy ta 4-ghidroksyfenilpiruvatdioksyhenazy u silskomu ghospodarstvi / A.M. Antonenko, M.M. Korshun, V.H. Bardov, O.M. Korshun // Dovkillia ta zdorovia. 2012. № 3. S. 59-65.

8. Porivnialna toksykoloho-hihienichna otsinka sulfonilsechovynnykh gherbizydiv z tryazynovymheterotsyklom (ohliad literatury ta rezultativ vlasnykh doslidzhen) / Korshun M.M. [ta in.] // Dovkillia ta zdorovia. 2010. № 4 (55). S. 54-63.

9. Agricultural Substances Databases Agriculture \& Environment Research Unit. University of Hertfordshire : electron resource. URL: http://sitem.herts.ac.uk/aeru/iupac/docs/Background_and_Support.pdf.

10. Gustafson D.I. Groundwater ubiquity score: a simple method for assessing pesticide leachability // Environmental Toxicology and Chemistry. 1989. № 8. P. 339-357.

11. Claudia A. Spadotto Screening method for assessing pesticide leaching potential // Pesticidas: R. Ecotoxicol. - Curitiba. 2002. Vol. 12, P. 69-78.

12. Indikatornye kriterii I prohnoz opasnosti zagryazneniia podzemnykh vod gerbitsidami na osnove efirov kislot / Sergeev S.G. [i dr.] // Sovremennye problemy toksikolohii. 2010. № 2-3. S. 76-79.

13. Pat. 105428 Ukraina, MPKA61V 10/00. Sposib prohnozuvannia nehatyvnoho vplyvu na zdorovia naselennia pestytsydiv pry yikh potraplianni v orhanizm z vodoiu / A.M. Antonenko, O.P. Vavrinevych, 
M.M. Korshun, S.T. Omelchuk, V.H. Bardov; vlasnyk Natsionalnyi medychnyi universytet imeni O.O. Bohomoltsia. - № u201506527; zaiavl. 03.07.2015; opubl. 25.03.2016, Biul. № 6.

14. Pat. 105429 Ukraina, MPK A61V 10/00. Sposib kompleksnoi otsinky ryzyku nehatyvnoho vplyvu na orhanizm liudyny pestytsydiv pry yikh vymyvanni u vodu / O.P. Vavrinevych, A.M. Antonenko, S.T. Omelchuk, M.M. Korshun; vlasnyk Natsionalnyi medychnyi universytet imeni O.O. Bohomoltsia. - № u201506528; zaiavl. 03.07.2015; opubl. 25.03.2016, Biul. № 6 .

15. EPA Home. Pesticides. Science \& Policy Models and Databases Water Models. URL: https://archive.epa.gov/oppefed1/web/html/index5.html\#scigrow

DOI https://doi.org/10.30525/978-9934-588-81-5-2.52

\title{
АНАЛІЗ СУЧАСНОГО СТАНУ ТА ПРОБЛЕМ ЕРГОТЕРАПІЇ ВІЙСЬКОВОСЛУЖБОВЦІВ ЗБРОЙНИХ СИЛ УКРАЇНИ, ПОСТРАЖДАЛИХ В РЕЗУЛЬТАТІ БОЙОВИХ ДІЙ
}

\author{
Купріненко О. В. \\ викладач кафедри фізичної терапї та ерготерапії \\ Львівський державний університет фізичної культури \\ імені Івана Боберського \\ Ціж Л. М. \\ кандидат наук з фізичного виховання і спорту, дочент, \\ в.о. завідувача кафедри фізичної терапії та ерготерапії \\ Львівський державний університет фізичної культури \\ імені Івана Боберського \\ м. Львів, Украӥна
}

3 початку тимчасової окупації Російською Федерацією Автономної Республіки Крим та розпалювання збройного конфлікту в східних регіонах України, участь в антитерористичній операції (АТО) та операції Об'єднаних сил (ООС) взяли понад 370 тисяч українців [1].

Шостий рік на Сході України триває війна. Відповідно до оперативного обліку втрат особового складу Збройних Сил (3С) України, за час проведення ATO (OOC) на території Донецької та Луганської областей кількість загиблих (померлих), поранених, травмованих, ушкоджених станом на 26.06.2018 становила 14439 осіб [2]. Найбільшу частку в структурі поранень військових складають поранення 194 